\title{
The Effect of Adding Ketamine or Midazolam to Bupivacaine for Ultrasound-Guided Supraclavicular Brachial Plexus Block for Upper Extremity Surgeries
}

\author{
MOHAMED Z. WFA, M.Sc.; MONA BLOUGH EL-MOURAD, M.D.; AYMAN A. YOUSEF, M.D. and \\ NADEA H. FETOUH, M.D.
}

The Department of Anesthesia, Surgical Intensive Care and Pain Management, Faculty of Medicine, Tanta University, Tanta, Egypt

\begin{abstract}
Background: The use of supraclavicular brachial plexus block is one of the most effective anesthetic techniques in operations for the upper extremity. The use of ultrasound guidance for regional anesthesia became popular owing to detection of anatomical variants, painless performance and correct needle placement. Aim of the study is to evaluate the value of adding ketamine or midazolam to bupivacaine when used for ultrasound guided supraclavicular brachial plexus block in upper extremity surgical procedures as regard the quality of surgical anesthesia and post-operative analgesia.

Patients and Methods: Seventy adult patients of both sexes aged (18-60) years with ASA physical status I/II scheduled for elective surgical procedure of the elbow, forearm, wrist and hand. Patients divided into two groups thirty-five patients were given $30 \mathrm{ml}$ total volume of $0.5 \%$ bupivacaine with midazolam $50 \mu \mathrm{g} / \mathrm{kg}$ injected around brachial plexus cluster (Group A) and thirty-five patients were given $30 \mathrm{ml}$ general volume contained $0.5 \%$ bupivacaine with ketamine $2 \mathrm{mg} / \mathrm{kg}$ injected around brachial plexus cluster (Group B).

Results: There was no significant difference among both groups according to demographic data, hemodynamic changes, onset of motor and sensory block, sedation score, total doses of rescue analgesia and incidence of complications. There was significant prolongation in duration of sensory and motor block, significant decrease in VAS and significant delay in first request of rescue analgesia in Group A.

Conclusion: The addition of midazolam $(50 \mu \mathrm{g} / \mathrm{kg})$ when used as adjuvants to bupivacaine in ultrasound guided brachial plexus block produced prolongation of sensory and motor block, providing desirable sedation, improved quality of postoperative analgesia and decreased necessities of rescue analgesics in post-operative period.
\end{abstract}

Key Words: Bupivacaine - Midazolam - Ketamine - Supraclavicular brachial plexus block - Ultrasound guided.

Correspondence to: Dr. Mohamed Z. Wfa, E-Mail: Dr.mohamedzakarea@gmail.com

\section{Introduction}

SUPRACLAVICULAR brachial plexus block is the most effective anesthetic procedure in surgeries of the upper extremity, it has surgical, and therapeutic purpose in interventional pain management [1].

It blocks the brachial plexus with much less requirement of anesthetic solution and rapid onset of action. The use of ultrasound has become popular due to its ability to come across the anatomical variants, painless performance and more correct needle placement [1]

Bupivacaine used frequently for supraclavicular nerve block because of its long duration of action 3-6hr. [2]. Numerous adjuvants had been used in brachial plexus block to improve the quality of duration of anesthesia and perioperative analgesia [3].

Ketamine is a noncompetitive antagonist of the N-Methyl-D Aspartate Receptor (NMDAR). It's used for sedation, it has central, regional, local anesthetic and analgesic effect [4].

Midazolam potentiates the impact of local anesthesia when used in neuroaxial block. It acts on Gamma Aminobutyric Acid-A (GABA-A) receptors which also found in peripheral nerves [5]

The objective of our study was to evaluate the impact of adding ketamine or midazolam to bupivacaine in ultrasound guided supraclavicular brachial plexus block in upper extremity procedures as regard the quality of surgical anesthesia and postoperative analgesia. 


\section{Patients and Methods}

After approval of Institutional Ethical Committee of Faculty of Medicine Tanta University. This study was registered in Pan African Clinical Trial Registry with unique identification number PACTR201706002029303. This study was carried out in Tanta University Hospitals between January 2016 and March 2017 on 70 adult patients of both sexes scheduled for optional surgical procedure of the elbow, forearm, wrist or hand, a written informed consent was obtained from all patients participated in the study.

Patients with neurological deficit of upper limbs, bleeding disorders or patients on anticoagulant therapy, intellectual dysfunctions, history of drug abuse, chronic analgesic use, hypersensitivity to local anesthetics or any of the study drugs and pregnant or lactating patients were excluded from the study. Patients were randomly allocated into two groups with the use of sealed envelopes. Thirtyfive patients received ultrasound guided supraclavicular brachial plexus block using $30 \mathrm{ml}$ overall volume contained $0.5 \%$ bupivacaine with midazolam $50 \mu \mathrm{g} / \mathrm{kg}$ (Group A). Thirty-five patients ultrasound guided supraclavicular brachial plexus block using $30 \mathrm{ml}$ overall volume contained $0.5 \%$ bupivacaine with ketamine $2 \mathrm{mg} / \mathrm{kg}$ (Group B).

Ordinary monitoring which includes ECG, noninvasive mean arterial blood pressure and pulse oximetry ( $\mathrm{SPO} 2)$ were implemented to the patient and intravenous line was established using $18 \mathrm{G}$ cannula, in the non-operated arm. Hemodynamics (MAP, HR) were measured at arrival to operating theatre then every 5 minutes till 30 minutes then every 15 minutes until 60 minutes, at recovery, at 30 and 60 minutes post-operatively.

The skin was disinfected with betadine solution $10 \%$. And a high frequency $12 \mathrm{MHz}$ (SonoScape $\AA$, SSI-6000, China) linear probe, protected with the aid of sterilized gloves was placed firmly over the supraclavicular fossa, the probe was positioned within the transverse plane advanced to the clavicle at approximately its midpoint. The probe was tilted caudally to achieve a move-sectional view of the subclavian artery. The brachial plexus become visible as a collection of hypoechoic oval structures lateral and superficial to the artery.

The patients were assessed for sensory block using pinprick test [6] (grade 0: Sharp pin felt, grade 1: Analgesia, dull sensation felt, grade 2: Anesthesia, no sensation). The onset of sensory block was recorded as the time taken from the end of the injection to the first dull response to pinprick
(Grade 1) in the distribution of the sensory nerves in the hand. Duration of sensory block was recorded as the time taken from injection of the drug till the first experience of Grade 0 (sharp pin felt).

The degree of motor block was assessed according to modified Bromage scale of upper extremities [6] (grade 0: Normal motor function with full flexion and extension of elbow, wrist and fingers, grade 1: Decrease motor strength with ability to move the fingers only, grade 2: Complete motor block with inability to move fingers). The onset of motor block was recorded as the time taken from end of injection until onset of complete loss of the motor power. We checked the degree of motor block every $5 \mathrm{~min}$ up to $30 \mathrm{~min}$.

The duration of motor block was recorded as the time taken between injection of the drug till the first experience of postoperative motor power recovery (Grade 0 ).

The patients were familiarized with a 10-point Visual Analog Scale (VAS) for pain [7], that ranged from $(0=$ no pain $)$ to $(10=$ the worst imaginable pain). Patients with VAS score $>4$ received rescue analgesia in the form of meperidine $25 \mathrm{mg}$ increments.

Sedation was measured using sedation score as follow [8] (grade 1: Awake and alert, grade 2: Responding to verbal stimulus, grade 2: Responding to verbal stimulus, grade 3: Responding to mild physical stimulus, grade 4: Responding to moderate-or-severe physical stimulus).

\section{Technique:}

Using a 25 -gauge needle, 1 to $2 \mathrm{~mL}$ of lidocaine was injected into the skin $1 \mathrm{~cm}$ lateral to the probe to decrease the discomfort for the duration of needle insertion. The needle must be inserted not deeper than $1 \mathrm{~cm}$ to keep away from inadvertent puncture of subclavian artery. The needle became superior alongside the long axis of the probe in the same plane of the ultrasound beam so the shaft and tip of the needle can be visualized when directed in the direction of the targeted nerves. The volume was injected under direct vision of ultrasound beams according to the respective groups.

Our primary outcome was quality of onset and duration of sensory and motor blockade and secondary outcome measurements were the onset of 1 st request of analgesia, degree of post-operative analgesia (VAS score), the need of rescue analgesia and sedation score. 


\section{Statistical analysis:}

Parametric data were analyzed using Student's $t$-test while non-parametric data were analyzed using $\chi$-tests or fisher exact test. Data were presented as mean and standard deviation. A $p$-value of less than 0.05 was considered significant.

Patients were randomly classified into two equal groups, the sample size calculation was estimated at $N>33$ in each group, so we enrolled 35 patients per group, based on the following criteria: $95 \%$ confidence limit, $80 \%$ power of study, ratio of Group A to Group B 1:1, and the expected outcome in Group A compared to Group B ranged $30 \%$ change according to the measurements.

\section{Results}

There was no significant difference between both groups regarding demographic data (age, gender, ASA physical status, types and duration of operation) (Table 1). There were no significant differences were detected in both groups as regards hemodynamic parameters (heart rate and blood pressure) (Tables 2,3).

Regarding onset sensory block there was no significant difference between both groups in Group A the onset of sensory block was $13.09 \pm 1.95 \mathrm{~min}$. in comparison to $14.31 \pm 3.14 \mathrm{~min}$ in Group B $(p=0.053)$, while there was significant prolongation of the duration of sensory block in Group A which was $11.09 \pm 3.76 \mathrm{hrs}$. compared to $3.54 \pm 0.74 \mathrm{hrs}$. in Group B ( $p=0.0001)$, and there was no significant difference between both groups regarding onset of motor block in Group A $12.086 \pm 1.422 \mathrm{~min}$. compared to $12.6 \pm 2.5 \mathrm{~min}$. in Group B $(p=0.2941)$. There was significant prolongation of motor blockade duration in Group A it was $11.97 \pm 3.69 \mathrm{hrs}$. compared to $3.63 \pm 0.69 \mathrm{hrs}$. in Group B ( $p=0.0001)$ (Table 4).

There was significant delay in 1st request of rescue analgesia in Group A ( $p=0.0001)$ and there was no significant difference between both groups regarding the total doses of rescue analgesia needed $(p=0.5201)$ (Table 5).

There was a significant decrease in VAS in Group A at $4,6,8$ and 10hrs. post-operatively ( $p=$ $0.0001,0.0001,0.0001$ and 0.006 ) respectively while there was no significant change in sedation score between both groups (Table 6).

Only two patients in Group A evolved chest discomfort compared to one patients in Group B, while one patient in each groups evolved horner's syndrome (Table 7).
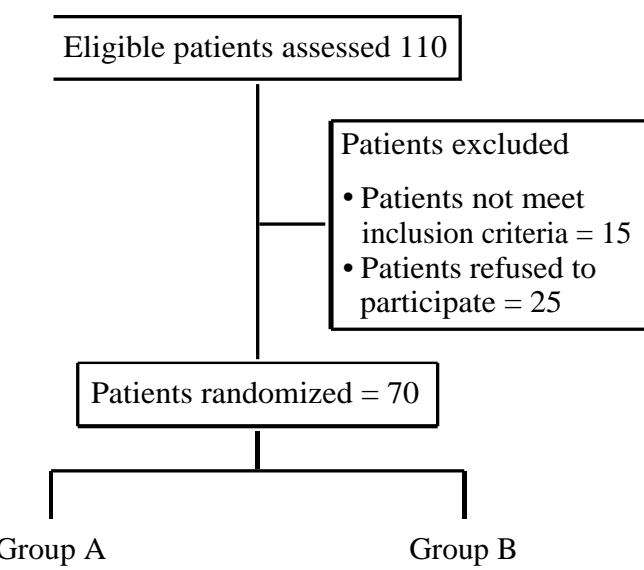

Thirty-five patients received ultrasound guided supraclavicular brachial plexus block using $30 \mathrm{ml}$ overall volume contained $0.5 \%$ bupivacaine with midazolam 50 go/leg

number of patients analyzed $=35$
Thirty-five patients received ultrasound guided supraclavicular brachial plexus block using $30 \mathrm{ml}$ overall volume contained $0.5 \%$ bupivacaine with ketamine $2 \mathrm{mg} / \mathrm{kg}$ number of patients analyzed $=35$
Fig. (1): Patients flow throughout the study.

Table (1): Demographic data of both groups.

\begin{tabular}{lcccc}
\hline $\begin{array}{l}\text { Demographic } \\
\text { data }\end{array}$ & $\begin{array}{c}\text { Group A } \\
(\mathrm{n}=35)\end{array}$ & $\begin{array}{c}\text { Group B } \\
(\mathrm{n}=35)\end{array}$ & $\begin{array}{c}\text { Test of sig. } \\
(t \text {-test- } \\
\text { Chi square })\end{array}$ & $\begin{array}{c}p \text { - } \\
\text { value }\end{array}$ \\
\hline $\begin{array}{l}\text { - Age (years }): \\
\quad \text { Mean } \pm \mathrm{SD}\end{array}$ & $36.14 \pm 12.27$ & $40.14 \pm 12.59$ & 1.35 & 0.18 \\
- Sex: \\
$\quad \mathrm{F} / \mathrm{M}$
\end{tabular}

Table (2): Mean values of mean arterial blood pressure in studied groups.

\begin{tabular}{lcccc}
\hline & $\begin{array}{c}\text { Group A } \\
\text { Mean } \pm \text { SD } \\
(\mathrm{n}=35)\end{array}$ & $\begin{array}{c}\text { Group B } \\
\text { Mean } \pm \text { SD } \\
(\mathrm{n}=35)\end{array}$ & $\begin{array}{c}\text { Unpaired } \\
t \text {-test }\end{array}$ & $\begin{array}{c}p \text { - } \\
\text { value }\end{array}$ \\
\hline Pre-operative & $87.4 \pm 3.8$ & $88.9 \pm 4.07$ & 1.54 & 0.13 \\
$10 \mathrm{~min}$ & $84.5 \pm 2.8$ & $85.7 \pm 2.9$ & 1.88 & 0.07 \\
$30 \mathrm{~min}$ & $87.9 \pm 2.5$ & $88.2 \pm 1.7$ & 0.51 & 0.61 \\
$45 \mathrm{~min}$ & $89.8 \pm 2.1$ & $90 \pm 2.8$ & 0.34 & 0.74 \\
$60 \mathrm{~min}$ & $89.7 \pm 2.44$ & $89.6 \pm 2.6$ & 0.19 & 0.85 \\
Recovery & $89.8 \pm 2.92$ & $90.14 \pm 2.7$ & 0.47 & 0.64 \\
60min & $90.5 \pm 2.5$ & $91.1 \pm 2.32$ & 0.99 & 0.324 \\
\hline
\end{tabular}


Table (3): Mean values of heart rate changes in studied groups.

\begin{tabular}{lllll}
\hline & $\begin{array}{c}\text { Group A } \\
\text { Mean } \pm \text { SD } \\
(\mathrm{n}=35)\end{array}$ & $\begin{array}{c}\text { Group B } \\
\text { Mean } \pm \text { SD } \\
(\mathrm{n}=35)\end{array}$ & $\begin{array}{c}\text { Unpaired } \\
t \text {-test }\end{array}$ & $\begin{array}{c}p \text { - } \\
\text { value }\end{array}$ \\
\hline Pre-operative & $84.22 \pm 6.17$ & $83.7 \pm 6.5$ & 0.14 & 0.75 \\
$10 \mathrm{~min}$ & $80.37 \pm 5.21$ & $82.3 \pm 4.5$ & 1.7 & 0.098 \\
$30 \mathrm{~min}$ & $83.3 \pm 3.8$ & $83.3 \pm 4.4$ & 0.058 & 0.95 \\
$45 \mathrm{~min}$ & $84.5 \pm 3.98$ & $84.6 \pm 4.26$ & 0.058 & 0.95 \\
60min & $83.6 \pm 3.7$ & $85 \pm 3.7$ & 1.6 & 0.122 \\
Recovery & $81.02 \pm 4.4$ & $82.34 \pm 4.64$ & 1.22 & 0.22 \\
60min & $79.3 \pm 2.3$ & $79.2 \pm 2.22$ & 0.211 & 0.834 \\
\hline
\end{tabular}

Table (4): Onset and duration of sensory and motor block.

\begin{tabular}{|c|c|c|c|c|}
\hline & $\begin{array}{c}\text { Group A } \\
(\mathrm{n}=35)\end{array}$ & $\begin{array}{c}\text { Group B } \\
(\mathrm{n}=35)\end{array}$ & $\begin{array}{l}\text { Test of sig. } \\
(t \text {-test- } \\
\text { Chi square })\end{array}$ & $\begin{array}{c}p- \\
\text { value }\end{array}$ \\
\hline $\begin{array}{l}\text { - Onset of } \\
\text { sensory block }\end{array}$ & $13.09 \pm 1.95$ & $14.31 \pm 3.14$ & 1.97 & 0.053 \\
\hline $\begin{array}{l}\text { - Onset of motor } \\
\text { block }\end{array}$ & $12.086 \pm 1.422$ & $12.6 \pm 2.5$ & 1.057 & 0.2941 \\
\hline $\begin{array}{l}\text { - Duration of } \\
\text { sensory block }\end{array}$ & $11.09 \pm 3.76$ & $3.54 \pm 0.74$ & 11.64 & 0.0001 \\
\hline $\begin{array}{r}\text { Duration of } \\
\text { motor block }\end{array}$ & $11.97 \pm 3.69$ & $3.63 \pm 0.69$ & 13.12 & 0.0001 \\
\hline
\end{tabular}

Table (5): Onset of 1 st dose and total doses of rescue analgesia.

\begin{tabular}{|c|c|c|c|c|c|c|}
\hline & \multicolumn{2}{|c|}{$\begin{array}{l}\text { Group A } \\
(\mathrm{n}=35)\end{array}$} & \multicolumn{2}{|c|}{$\begin{array}{l}\text { Group B } \\
(\mathrm{n}=35)\end{array}$} & $\begin{array}{l}\text { Test of sig. } \\
(t \text {-test- } \\
\text { Chi square })\end{array}$ & $\begin{array}{c}p- \\
\text { value }\end{array}$ \\
\hline $\begin{array}{l}\text { - Mean of 1st dose } \\
\text { of rescue } \\
\text { analgesia (hrs.) }\end{array}$ & \multicolumn{2}{|c|}{$15 \pm 3.2$} & \multicolumn{2}{|c|}{$6.8 \pm 1.03$} & 8.3 & 0.0001 \\
\hline $\begin{array}{l}\text { - Mean values of } \\
\text { rescue analgesia } \\
(\mathrm{mg})\end{array}$ & \multicolumn{4}{|c|}{$28.13 \pm 8.8431 .25 \pm 11.31$} & 0.656 & 0.5201 \\
\hline $\begin{array}{l}\text { - Number of patients } \\
\text { need rescue }\end{array}$ & No. & $\begin{array}{l}\text { Percen- } \\
\text { tage }\end{array}$ & No. & $\begin{array}{l}\text { Percen- } \\
\text { tage }\end{array}$ & & \\
\hline $\begin{array}{l}\text { Yes } \\
\text { No }\end{array}$ & $\begin{array}{l}8 \\
27\end{array}$ & $\begin{array}{l}22.9 \% \\
77.1 \%\end{array}$ & $\begin{array}{l}12 \\
23\end{array}$ & $\begin{array}{l}34.3 \% \\
65.7 \%\end{array}$ & 0.63 & 0.427 \\
\hline $\begin{array}{l}\text { - Number of rescue } \\
\text { analgesia doses: } \\
\text { Rescue analgesia } \\
\text { No rescue }\end{array}$ & $\begin{array}{l}9 \\
27\end{array}$ & $\begin{array}{l}25.7 \% \\
77.1 \%\end{array}$ & $\begin{array}{l}15 \\
23\end{array}$ & $\begin{array}{l}42.8 \% \\
65.7 \%\end{array}$ & 1.78 & 0.18 \\
\hline
\end{tabular}

Table (6): Mean values of sedation score in standard groups.

\begin{tabular}{|c|c|c|c|c|c|c|c|c|c|c|}
\hline & \multicolumn{4}{|c|}{$\begin{array}{c}\text { Group A } \\
(n=35)\end{array}$} & \multicolumn{4}{|c|}{$\begin{array}{l}\text { Group B } \\
(\mathrm{n}=35)\end{array}$} & \multirow{2}{*}{$\begin{array}{l}\text { Chi- } \\
\text { square }\end{array}$} & \multirow{2}{*}{$\begin{array}{c}p- \\
\text { value }\end{array}$} \\
\hline & G1 & $\mathrm{G} 2$ & G3 & G4 & G1 & G2 & G3 & G4 & & \\
\hline Intraoperative & 10 & 25 & 0 & 0 & 7 & 28 & 0 & 0 & 0.311 & 0.29 \\
\hline \multicolumn{11}{|l|}{ Post-operative } \\
\hline $\begin{array}{l}\text { Arrival to recovery } \\
\text { unit }\end{array}$ & 35 & 0 & 0 & 0 & 35 & 0 & 0 & 0 & - & 1 \\
\hline $4 \mathrm{~h}$ & 35 & 0 & 0 & 0 & 35 & 0 & 0 & 0 & - & 1 \\
\hline $8 \mathrm{~h}$ & 35 & 0 & 0 & 0 & 35 & 0 & 0 & 0 & - & 1 \\
\hline $12 \mathrm{~h}$ & 35 & 0 & 0 & 0 & 35 & 0 & 0 & 0 & - & 1 \\
\hline $18 \mathrm{~h}$ & 35 & 0 & 0 & 0 & 35 & 0 & 0 & 0 & - & 1 \\
\hline
\end{tabular}

Table (7): Complications of both groups.

\begin{tabular}{lcccccccc}
\hline \multirow{2}{*}{ Complication } & \multicolumn{2}{c}{$\begin{array}{c}\text { Group A } \\
(\mathrm{n}=35)\end{array}$} & & \multicolumn{2}{c}{$\begin{array}{c}\text { Group B } \\
(\mathrm{n}=35)\end{array}$} & $\begin{array}{c}\text { Chi- } \\
\text { square }\end{array}$ & $\begin{array}{c}p- \\
\text { value }\end{array}$ \\
\cline { 2 - 3 } & $\mathrm{N}$ & $\%$ & & $\mathrm{~N}$ & $\%$ & & \\
\hline Horner's syndrome & 1 & 2.8 & & 1 & 2.8 & - & 1 \\
Chest discomfort & 2 & 5.7 & & 1 & 2.8 & 0.35 & 0.56 \\
Pneumothorax & 0 & 0 & & 0 & 0 & - & 1 \\
Voice changes & 0 & 0 & & 0 & 0 & - & 1 \\
\hline Total complications & 3 & 8.51 & & 2 & 5.6 & 0.22 & 0.64 \\
\hline
\end{tabular}

\section{Discussion}

Regional anesthesia techniques are often used to provide not only anesthesia but also postoperative analgesia after surgery. Brachial plexus block is a versatile and reliable regional anesthesia technique and suitable alternative to general anesthesia for upper limb surgery. Adjuvants to local anesthetics have been added in order to shorten the onset time, increase the quality and duration of brachial plexus block resulting in smooth postoperative outcome.

The study was designed to compare the effect of adding midazolam as and ketamine as adjuvants to bupivacaine and the study showed significantly increase in the duration of sensory and motor block, significant lower postoperative visual analogue score at ( $4 \mathrm{~h}, 6 \mathrm{~h}, 8 \mathrm{~h}, 10 \mathrm{~h}$ and $18 \mathrm{~h})$, significant increase the onset of 1 st dose of analgesic requirement, increasing number of patients needed analgesia post-operatively and there was no statistically significant difference in sedation scores between both groups.

We claim that our results were due to midazolam, a water soluble, short acting benzodiazepine which produces analgesia by acting on gamma amino butyric acid (GABA) receptors. Extra synaptic receptors for GABA are present on myelinated axons of peripheral nerves. Various studies demonstrated the efficacy of midazolam as an adjuvant to local anesthesia in intrathecal [9], caudal [10] and epidural routes as it prolongs post-operative analgesia [11]. While the mechanism by which ketamine acts by blocking N-Methyl-D-Aspartate (NMDA) receptor. Various studies demonstrated the efficacy of ketamine when used in premedication [12], sedation [13], induction, and maintenance of general anesthesia [14].

According to hemodynamics our results showed agreement with Nalwaya et al., [15] compared between two groups one group received bupivacaine $(0.5 \%)$, Lignocaine $(2 \%)$ with Adrenaline $(1: 2,00,000)$ versus midazolam in addition to these drugs using ultrasound guided supraclavicular 
brachial plexus block showed no statistically significant distinction in mean arterial blood pressure and heart rate, in addition Lashgarinia [16] sixty adult patients undergoing supraclavicular brachial plexus block ultrasound guided for surgeries of the elbow, forearm, wrist or hand, randomly allocated in two groups of 30 patients each. Ketamine group received $5 \mathrm{mg} / \mathrm{kg}$ lidocaine $1.5 \%$ plus $2 \mathrm{mg} / \mathrm{kg}$ ketamine, the other group received $5 \mathrm{mg} / \mathrm{kg}$ lidocaine $1.5 \%$ and saline confirmed no statistically considerable difference in mean arterial blood pressure and heart rate between ketamine with bupivacaine versus bupivacaine only. Studies showed agreement with our study according to onset of sensory and motor block as Shaikhl et al., [17] added midazolam to bupivacaine in comparison to saline with bupivacaine showed no statistically significant difference in onset of sensory and motor block, Senel et al. [18] compared tramadol with ropivacaine compared to ketamine with ropivacaine, and there was no statistically significant difference in onset of motor and sensory block, Panda NB et al., [19] was in agreement with our study as he added midazolam as an adjuvant to bupivacaine in brachial plexus block compared to bupivacaine and showed prolongation of the duration of sensory block in group received midazolam, and according to ketamine Lee et al. [20] compared between ropivacaine, ropivacaine with ketamine as adjuvants and ropivacaine with $30 \mathrm{mg}$ ketamine intravenous showed no significant change between both groups regard duration of sensory and motor block, there was lower visual analogue score in group received midazolam and this was in agreement to Shaikh et al. [17] added midazolam to bupivacaine in comparison to saline with bupivacaine confirmed lower visual analogue score in group received midazolam, according to 1 st dose of analgesia in group received midazolam Nalwaya D et al., [15] study showed that 1 st dose of analgesia was significantly higher in group received midazolam and according to group received ketamine Senel AC et al., [18] showed that onset of 1 st dose of analgesia needed in ketamine group was shorter than the other two groups. In agreement to our study regarding requirements of analgesia Shaikh et al. [17] added midazolam to bupivacaine in comparison to saline with bupivacaine showed reduction in requirement of analgesia in patients received midazolam. Panda et al. [19] showed agreement to our results as midazolam used as an adjuvant to bupivacaine and sedation score in group received midazolam was higher than the other group. Nalwaya et al. [15] proven that no patients suffered airway compromise or required airway guide. Our study had some limitations. First; the sample size wasn't large. Second, although our study was a randomized clinical trial, we didn't have a control group, which makes it difficult to put our results into perspective.

We concluded the addition of midazolam with dose $(50 \mathrm{tg} / \mathrm{kg})$ was better than ketamine with dose $(2 \mathrm{mg} / \mathrm{kg})$ when both used as adjuvants to bupivacaine in ultrasound guided brachial plexus block as demonstrated by prolongation duration of sensory block, improved quality of post-operative analgesia and reduced requirements of rescue analgesics in post-operative periods and providing desirable sedation without any side effects. We recomend to use higher concentration of ketamine as an adjuvant to local anesthetics in brachial plexus block to enhance the onset and duration of sensory and motor block.

\section{References}

1- TRAN D.Q.H., CLEMENTE A., DOAN J. and FINLAYSON R.J.: Brachial plexus blocks: A review of approaches and techniques. Canadian Journal of Anesthesia, 54: 66274, 2007.

2- NEAL J.M., GERANCHER J.C., HEBL J.R., ILFELD B.M., McCARTNEY C.J., FRANCO C.D. and HOGAN Q.H.: Upper extremity regional anesthesia: Essentials of our current understanding, 2008. Regional anesthesia and pain medicine, 34 (2): 134, 2009.

3- LASHGARINIA M., NAGHIBI K., HONARMAND A., SAFAVI M. and KHAZAEI M.: Effect of ketamine as an adjuvant in ultrasound-guided supraclavicular brachial plexus block. Advanced Biomedical Research, 3: 232, 2014.

4- VADIVELU N., SCHERMER E., KODUMUDI V., BELANI K., URMAN R.D. and KAYE A.D.: Role of ketamine for analgesia in adults and children. Journal of Anesthesiology, Clinical Pharmacology, 32 (3): 298, 2016.

5- SHAH F.R., HALBE A.R., PANCHAL I.D. and GOODCHILD C.S.: Improvement in post-operative pain relief by the addition of midazolam to an intrathecal injection of buprenorphine and bupivacaine. European Journal of Anesthesiology, 20 (11): 904-10, 2003.

6- ELSIED A.H., STEYN M.P. and ANSERMINO J.M.: Clonidine prolongs the effect of ropivacaine for axillary brachial plexus blockade. Canadian Journal of Anesthesia, 47 (10): 962-7, 2000.

7- FONTANAROSA P.B. and RAMSAY M.A.: Measuring level of sedation in the intensive care unit. Journal of American Medical Association, 284 (4): 441-2, 2000.

8- KOROGLU A., DEMIRBILEK S., TERKSAN H., SAGIR O. and EROSY M.O.: Sedative, haemodynamic and respiratory effects of dexmedetomidine in children undergoing magnetic resonance imaging examination: Preliminary results. British Journal of Anaesthesia, 94 (6): 821-4, 2005 . 
9- TUCKER A.P., MEZZATESTA J., NADESON R. and GOODCHILD C.S.: Intrathecal midazolam II: Combination with intrathecal fentanyl for labor pain. Anesthesia and Analgesia, 98: 1521-7, 2004.

10- JARINESHIN H., FEKRA F. and KERMANSHAH A.K. Treatment of Post-operative Pain in Pediatric Operations: Comparing the Efficiency of Bupivacaine, BupivacaineDexmedetomidine and Bupivacaine-Fentanyl for Caudal Block. Anesthesiology and pain medicine, 6 (5): 1-10, 2016.

11- GHAI B., MAKKAR J.K., CHARI P. and RAO K.L.: Addition of midazolam to continuous postoperative epidural bupivacaine infusion reduces requirement for rescue analgesia in children undergoing upper abdominal and flank surgery. Journal of Clinical Anesthesia, 21 (2): 113 9, 2009.

12- SAJEDI P. and HABIBI B.: Comparison of the effects of intravenous premedication: Midazolam, Ketamine, and combination of both on reducing anxiety in pediatric patients before general anesthesia. Journal of research in pharmacy practice, 4 (4), 187, 2015.

13- ISBISTER G.K., CALVER L.A., DOWNES M.A. and PAGE C.B.: Ketamine as rescue treatment for difficultto-sedate severe acute behavioral disturbance in the Emergency Department. Annals of Emergency Medicine, 67 (5), 581-7, 2016.

14- FURUYA A., MAT SUKAWA T., OZAKI M., NISHIYAMA T., KUME M. and KUMAZAWA T.: Intravenous ketamine attenuates arterial pressure changes during the induction of anaesthesia with propofol. European Journal of Anaesthesiology, 18 (2): 88-92, 2001.

15- NALWAYA D., OZA V., BATWARA D., VYAS A. and PARMAR V.: Efficacy of midazolam co-administered along with local anaesthetic solution in brachial plexus block. International Journal of Biomedical Research, 9: 571-5, 2014.

16- LASHGARINIA M., NAGHIBI K., HONARMAND A., SAFAVI M. and KHAZAEI M.: Effect of ketamine as an adjuvant in ultrasound-guided supraclavicular brachial plexus block: A double-blind randomized clinical trial study. Advanced Biomedical Research, 3, 2014.

17- SHAIKH I., SAFIYA and VEENA K.: Midazolam as an adjuvant in supraclavicular brachial plexus block. Anaesthesia, Pain \& Intensive Care, 16 (1): 7-12, 2012.

18- SENEL A.C., UKINC O. and TIMURKAYNAK A.: Does the Addition of Tramadol and Ketamine to Ropivacaine Prolong the Axillary Brachial Plexus Block? Biomedical Research International Journal, 1-5, 2014.

19- JARBO K., BATRA Y.K., NIDHI M. and PANDA B.: Brachial plexus block with midazolam and bupivacaine improves analgesia. Canadian Journal of Anesthesia, 52 (8): 822-6, 2005.

20- LEE I.O., KIM W.K., KONG M.H., LEE M.K., KIM N.S., CHOI Y.S. and LIM S.H.: No enhancement of sensory and motor blockade by ketamine added to ropivacaine interscalene brachial plexus blockade. Acta Anesthesiologica Scandinavica, 46: 821-6, 2002.

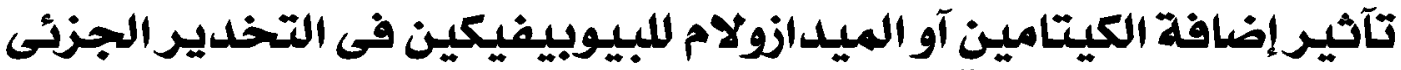

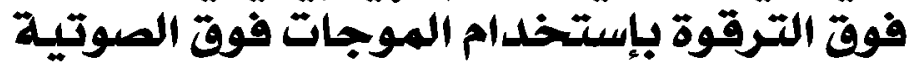

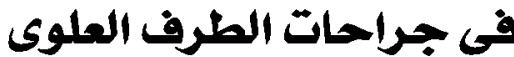

تخدير كتلة الضفيرة فوق الترقوة العضدية هى واحدة من إجراءات التخدير الآكثر فعالية فى عمليات الطرف العلوى، وقد آصبح تخدير

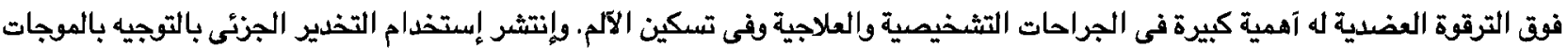

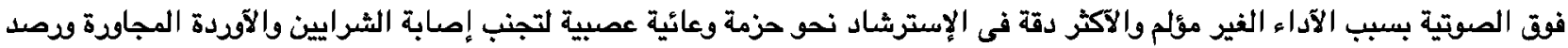
إنتشار المخدر فى المكان الصحيح وتجنب حدوث إسترواح الصدر وثئق الإستر الشرايين والتلف المباشر للآعصاب.

الهدف من هذه الدراسة هو تقييم تآثير إضافة الكيتامين والميدازولام اللبيوبيفيكين عند إستخداهها فى تخدير فوق الترقوة العضدية معتمدا

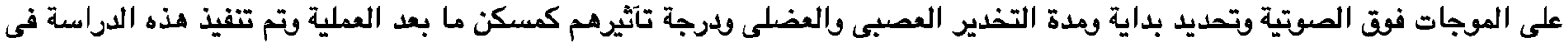

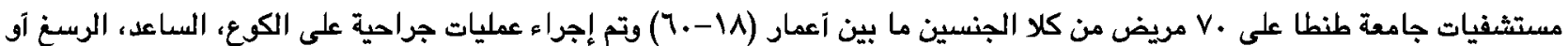

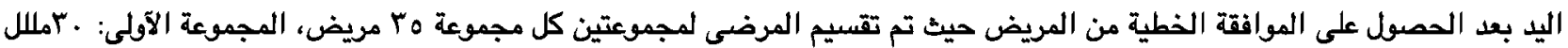

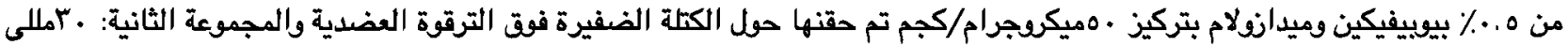

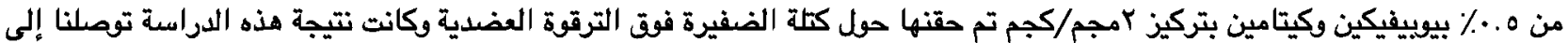

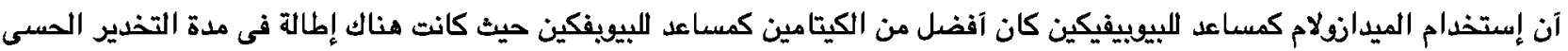

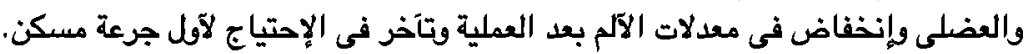

